\title{
Lethal and sublethal effects of metal-polluted sediments on Chironomus sancticaroli Strixino and Strixino, 1981
}

\author{
Frederico Guilherme de Souza Beghelli $\mathbb{B}^{1}$ • Julio César Lopez-Dovál ${ }^{2,3} \cdot$ André Henrique Rosa $^{1}$ • \\ Marcelo Pompêo ${ }^{1,2} \cdot$ Viviane Moschini Carlos ${ }^{1}$
}

Accepted: 5 January 2018 / Published online: 25 January 2018

(c) Springer Science+Business Media, LLC, part of Springer Nature 2018

\begin{abstract}
The Cantareira Complex is one of the most important water supplies of the metropolitan region of São Paulo, Brazil. Previously, it was demonstrated that the sediments in this complex were polluted with metals and that Paiva Castro Reservoir -the last reservoir in the sequence, which receives water from the five previous reservoirs-was the reservoir with the greatest concentration of pollutants. Based on field data, it was noticed that copper concentrations in sediments were related to morphological alterations in chironomids. The present study provides novel monitoring methods and results for the complex by isolating the environmental and biological sources of variation. An adaptation of the in situ assay proposed by Soares et al. (Arch Environ Contam Toxicol 49:163-172, 2005), which uses a native tropical Chironomus species and lowcost materials, is also provided. The aim of this study was to isolate the effects of sediments from Paiva Castro on controlled populations of $C$. sancticaroli larvae using an in situ assay. A seven-day experiment was performed in triplicate. Third instar larvae were inoculated in chambers containing sediments from two distinct regions of Paiva Castro reservoir and a control site with sand. Five biological responses were considered: mouthpart alterations, larval length, width of cephalic capsule, mortality and total damage. The results suggest the effects of sediment toxicity on larvae include a reduction in length and a higher occurrence of total damage.
\end{abstract}

Keywords Ecotoxicology $\cdot$ Metal pollution $\cdot$ Chironomid $\cdot$ Bio-indicator

\section{Introduction}

Ecotoxicological assays have provided important contributions to environmental monitoring, especially in relation to the development of environmental quality standards and indexes. From these studies, environmental risk analyses become more accurate, particularly when both ecotoxicological and field data are considered together (United States Environmental Protection Agency - US-EPA 1996;

Frederico Guilherme de Souza Beghelli fred_sb@hotmail.com

1 Programa de Pós-Graduação em Ciências Ambientais - Instituto de Ciência e Tecnologia de Sorocaba, UNESP, Avenida Três de Março, 511 - Alto da Boa Vista, Rio de Janeiro 18087-180, Brazil

2 Departamento de Ecologia - Instituto de Biociências, Universidade de São Paulo, Rua do Matão, 321, travessa 14 Cidade Universitária, São Paulo 05508-090, Brazil

3 Catalan Institute for Water Research (ICRA), Carrer Emili Grahit 101, Girona 17003, Spain
Canadian Council of the Ministers of the Environment CCME 2001; Environmental Protection Agency of São Paulo State - CETESB CETESB 2015; Pereira et al. 2015).

Chironomus larvae can be found in sediments of many continental aquatic environments. The genus is usually recorded as a common and abundant taxon, especially in impaired ecosystems (Oliveira et al. 2010; Machado et al. 2015). Chironomus larvae are recommended as bioindicators in and in ecotoxicological assays (Di Veroli et al. 2012, 2014). These dipterans are distributed worldwide, and they can inhabit almost any continental aquatic environment. Furthermore, Chironomus larvae are tolerant to manipulation and are easy to identify in cultures because of their size and red color (Fonseca and Rocha 2004).

Nikinmaa (2014) recommends that some criteria, such the climate zone and the relevance of the test organism to the study environment, must be considered, especially when investigating the effects of disturbances on ecosystems. The scarcity of model organisms from tropical environments is also recognized by Nikinmaa (2014). Chironomus sancticaroli Strixino and Strixino 1981 is a chironomid species 
that naturally occurs in South American ecosystems. For comparison with other studies and for taxonomic purposes, in this work, we considered this species to be the same species reported as Chironomus xanthus Rempel 1939. However, the notation $C$. sancticaroli agrees with the position adopted by Trivinho-Strixino (2011a).

Strixino and Trivinho-Strixino (1985) and TrivinhoStrixino and Strixino $(1982,1989)$ described the life cycle of $C$. sancticaroli and recorded the effects of temperature and nutrition on fecundity and larval development. They established the ideal conditions for rearing this tropical species in the laboratory. Other relevant contributions on the development of $C$. sancticaroli included the time intervals required to reach eclosion, to emerge and to achieve each instar stage. More recently, Fonseca and Rocha (2004) re-described the life cycle of C. sancticaroli considering different food resources, and they reached similar results in relation to the time intervals required to reach each instar as well as larval length and cephalic capsule width. These works were fundamental to providing a solid baseline for the development of bioassays with Chironomus in tropical regions. Before these studies, there was a predominance of results from tests using species typical of temperate regions.

Metals are pollutants of great concern in limnology. Their relevance is especially related to their persistence in the environment. Consequently, metals may accumulate and reach high concentrations in sediments of waterbodies with a history of pollution (Stanaway et al. 2012), cause damage to aquatic life ( $\mathrm{Li}$ et al. 2015) or even cause public health problems (Singh et al. 2014).

Metal toxicity is determined by multiple variables, and some biological and chemical properties must be considered. The chemical properties of the metals and their compounds, the biological properties of an organism and the environmental conditions are all determinants. Considering the confusion promoted by the use of the term "heavy metals" and other terms frequently used to describe the potential toxicity of metallic elements, the International Union of Pure and Applied Chemistry (IUPAC) recommended abandoning the term. Duffus (2002) recommended using a classification based on the general chemical reactivity properties. One of these classifications is based on the last electron subshell in the atom to be occupied. Metallic elements of toxicological interest are usually those included in the $d$ or $p$ blocks of the periodic table. This classification reflects the general reactivity of the elements. Metals included in $p$ block generally form complexes that are more stable than the weak complexes usually formed by the elements included in the $s$ block, i.e., the alkali metals, with low toxicological meaning. Furthermore, the higher atomic number $p$-block metals tend to bind strongly to sulfur, forming complexes that are relatively immobile in the environment and which tend to accumulate in organisms. Elements included in the $d$ block have a wide range of complex formation behaviors and redox properties. Additionally, the $d$-block elements can interfere in enzymatic activities.

As an example, Shanker et al. (2005) summarized the effects of chromium (a $d$-block metal) in plants, including bioaccumulation and many metabolic dysfunctions related to the modification of enzymatic activities. Another example of the possible impacts of $d$-block metals in living organisms comes from the work of Macomber and Imlay (2009). These authors elucidated the physiological mechanism behind the toxicity of copper in E. coli and verified the toxic effects of excessive copper in relation to alterations in the activity of an iron-sulfur cluster enzyme. This alteration is probably related to the reaction between $\mathrm{Cu}$ (I) and sulfur atoms. The metallic elements $\mathrm{Cr}, \mathrm{Fe}, \mathrm{Co}$, $\mathrm{Ni}, \mathrm{Cu}, \mathrm{Zn}$ and $\mathrm{Cd}$ are included in the $d$ block, while $\mathrm{Pb}$ and As are classified in the $p$ block.

The lethal and sublethal effects of metal pollution on Chironomus larvae were recorded by ecotoxicological (Roman et al. 2007; Di Veroli et al. 2012) and field studies (Cortelezzi et al. 2011; Di Veroli et al. 2014). Different types of sublethal effects have been reported as the result of several laboratory assays using Chironomus. Among the previously reported sublethal effects, it must be mentioned that morphological effects (Cortelezzi et al. 2011; Di Veroli et al. 2014) and energetic effects are also related to the developmental (Péry et al. 2003), physiological (Sérvia et al. 2006) and genetic effects (Jeppe et al. 2014; Planelló et al. 2015).

Dornfeld et al. (2006) conducted a pioneering in situ assay with $C$. sancticaroli larvae. The authors could not associate biological responses with environmental toxicity variation and concluded that the methodology used in the in situ assay needed to be improved because of the high mortalities that were observed under good environmental conditions. There are no other available records in the literature of $C$. sancticaroli in situ assays in tropical regions.

The Paiva Castro Reservoir belongs to the Cantareira Complex, which is a complex of interconnected reservoirs and rivers that supply approximately $45 \%$ of the water demand of the 20 million people in the Metropolitan Region of São Paulo, i.e., the most populous region of Brazil (São Paulo State Basic Sanitation Company - SABESP 2017). The Paiva Castro Reservoir is the last one in the complex and receives waters from the previous reservoirs and rivers by gravity. Water accumulates in this reservoir and is then pumped into a final accumulation reservoir and distributed (Fig. 1). The use of copper sulfate, urbanization, forest suppression, and agriculture all impact this reservoir (Whately and Cunha 2007). 


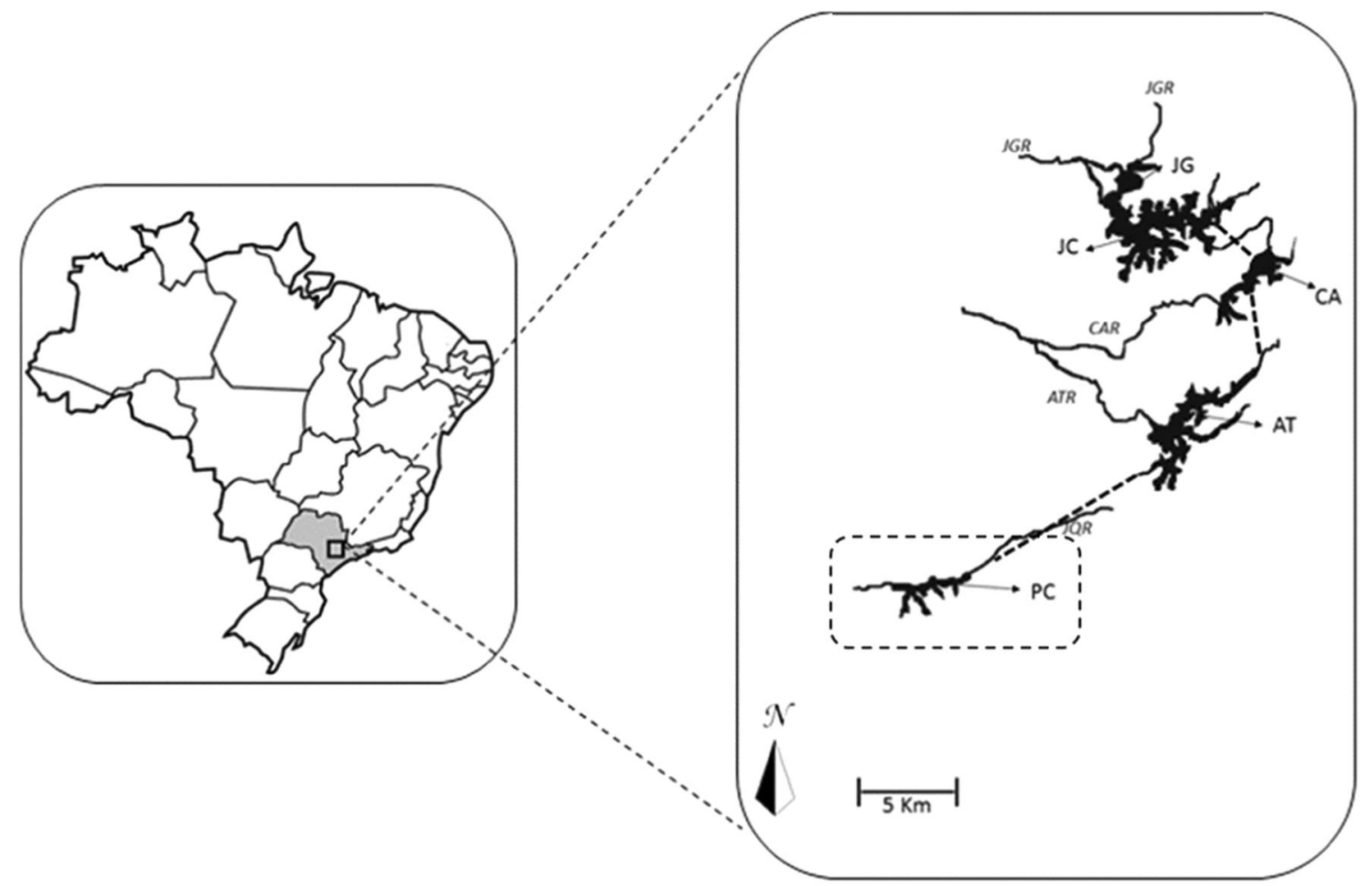

Fig. 1 Localization and map showing the Cantareira Complex, São Paulo, Brazil. Abbreviations in the map indicate the rivers Jaguari (JGR), Cachoeira (CAR), Atibaia (ATR) and Juqueri (JQR). The

In a previous study on Paiva Castro Reservoir, pollution by metallic elements $(\mathrm{Cd}, \mathrm{Cr}, \mathrm{Cu})$ and high concentrations of $\mathrm{Al}$ and $\mathrm{Fe}$ were recorded in the sediments of the littoral zone (Beghelli et al. 2014). Moreover, sediments from profundal regions in Paiva Castro were also considered polluted by copper and had concentrations of $\mathrm{Al}, \mathrm{Fe}$ and $\mathrm{Zn}$ above the background levels (Cardoso-Silva et al. 2016). As a result, morphological alterations related to copper pollution were reported in a recent investigation of littoral benthic macroinvertebrates from the Cantareira Complex (Beghelli et al. 2016).

Even when considering that only field studies can provide scientists with the real-world situation occurring between organisms and the environment, field studies can still introduce some difficulties in the final interpretation of the relationship between cause and consequence. These uncertainties are generally attributed to the fact that field studies have many sources of interference that cannot be detected (or predicted) completely by scientists. To minimize this probable bias, field data must be complemented by studies with higher degrees of control of environmental variables; this approach aims to produce more accurate results by providing additional support to the evidence from field studies (Betinetti et al. 2012).

The aims of this study were to test the effects of sediments from Paiva Castro on $C$. sancticaroli larvae in an
Cantareira Complex reservoirs are Jaguari (JG), Jacareí (JC), Cachoeira (CA), Atibaia (AT) and Paiva Castro (PC)

in situ assay and to establish the lethal and sublethal endpoints that can be monitored using in situ assays with $C$. sancticaroli. Our hypothesis was that, in the assays, benthic macroinvertebrates may respond to sediment metal pollution as a function of theoretical metal toxicity in sediments. Mortality, morphological alterations and total damages were expected to be highest in the most polluted sediments, while body length was expected to vary in the opposite sense. The head width was not expected to vary significantly between treatments.

\section{Methodology}

\section{Sampling}

Sediment samples were collected in a cumulative sample composed of three dredgings using an Ekman dredge (208 $\mathrm{cm}^{2}$ ). The central portion of each dredging sample was carefully separated and homogenized manually using a plastic glove. Sediment samples were collected in October 2014 from two distinct sampling stations in the littoral zone of Paiva Castro Reservoir (Fig. 2). As a reference, Table 1 shows the metal concentrations previously measured in water and sediments (Beghelli et al. 2014) from samples collected on July 24th, 2013. 


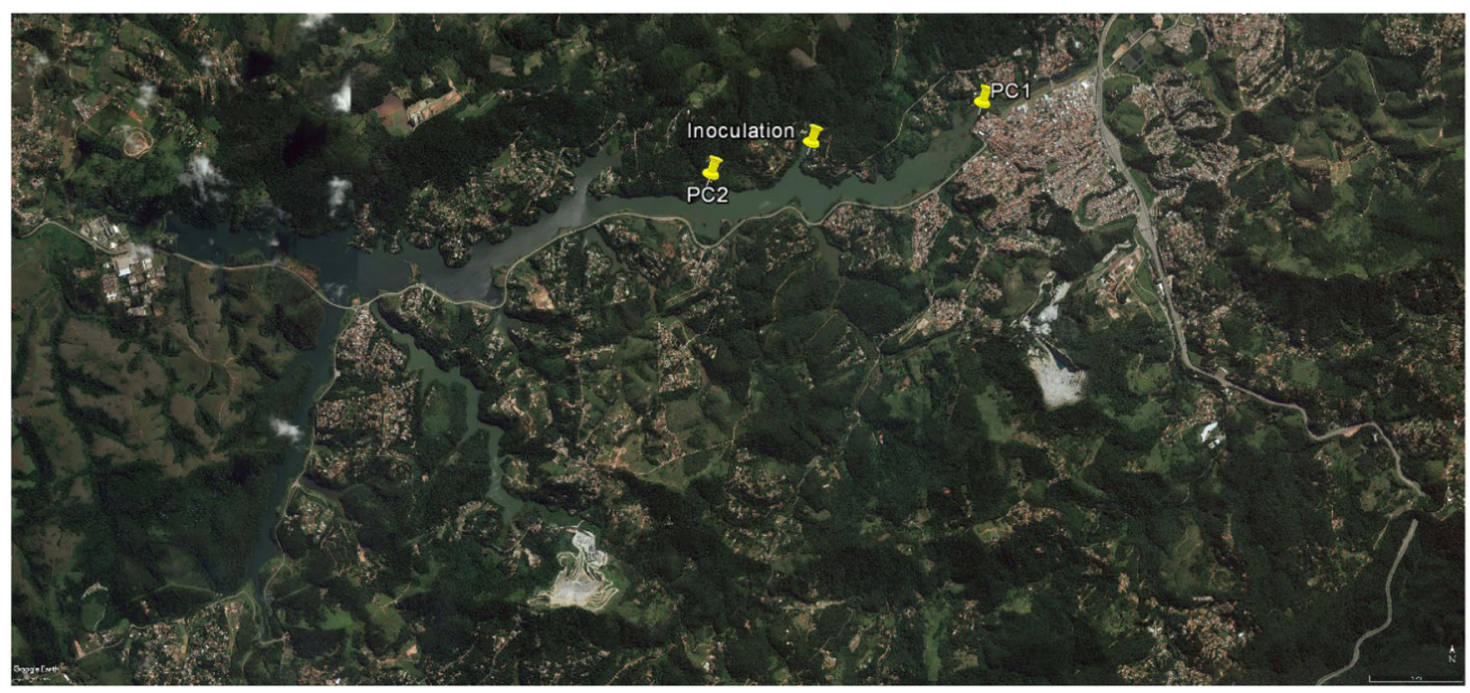

Fig. 2 Satellite imagery showing the Paiva Castro reservoir. The sampling stations PC1 and PC2 and the experimental station are indicated. Source: Google Earth ® Image 2017 Digital Globe

Table 1 Water and sediment concentrations of metallic elements according to previous data

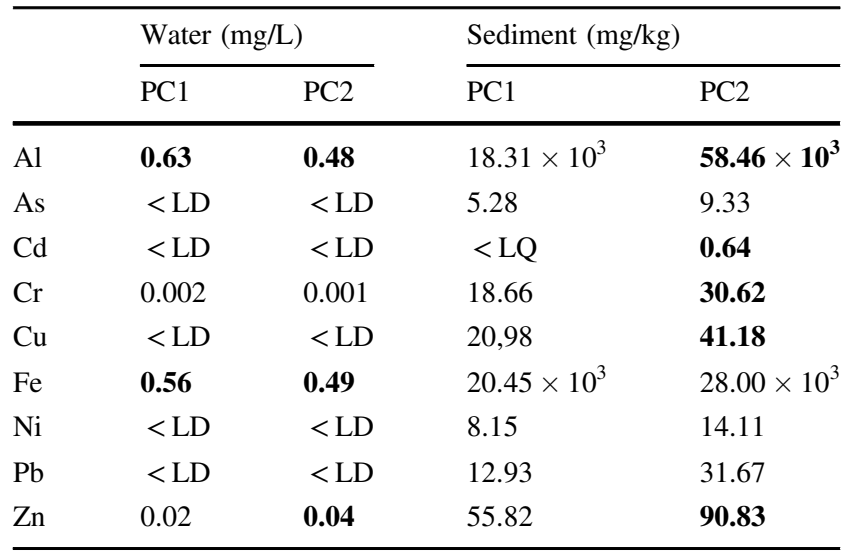

Bold values indicate concentrations above the thresholds recommended by the Canadian Councilf of the Ministers of Environment (CCME) for water samples or above the reference values for Paiva Castro sediments (Cardoso-Silva et al. 2016)

A subsample of each sample was separated for the determination of the metal concentrations and the proportion of organic matter. The remaining portions of each sample were frozen to avoid sediment contamination caused by larvae from the environment (Printes et al. 2011).

\section{Culture conditions}

C. sancticaroli larvae were obtained from a controlled culture maintained at the Laboratory of Limnology of Biosciences Institute of São Paulo University (USP). The culture was maintained in aquaria filled with Minalba ${ }^{\circledR}$ mineral water. The ionic composition of the water, according to the distributor, is shown in Table 2.
Table 2 Ionic composition of water used in the cultures

\begin{tabular}{ll}
\hline Ion & Concentration $(\mathrm{mg} / \mathrm{L})$ \\
\hline $\mathrm{Ca}^{++}$ & 17.107 \\
$\mathrm{~K}^{+}$ & 1.024 \\
$\mathrm{Mg}$ & 9.076 \\
$\mathrm{Na}^{+}$ & 0.924 \\
$\mathrm{Nitrite}^{+}$ & 0.700 \\
Sulfate & 0.130 \\
Chloride & 0.110 \\
Barium & 0.021 \\
Fluoride & 0.050 \\
Strontium & 0.019 \\
Bicarbonate & 97.510 \\
\hline
\end{tabular}

The aquaria were placed in an incubator at a controlled temperature $\left(24 \pm 2^{\circ} \mathrm{C}\right)$ and photoperiod $(12 \mathrm{~h}), \mathrm{a} \mathrm{pH}=6 \pm$ 0.3 and an average electrical conductivity of $2.7 \pm 40 \mu \mathrm{S} /$ $\mathrm{cm}$. A suspension of fish food (Nutrafish $®$ ) was periodically added to the cultures, maintaining the proportion of 5 $\mathrm{g} / \mathrm{L}$ (Mozeto et al. 2006).

\section{Experimental design and conditions}

The frozen sediments from PC1 and PC2 were thawed $24 \mathrm{~h}$ before the experiment. A separate control condition was prepared with aquarium sand that was previously washed and calcinated.

Prior to the experiment, three egg masses were separated from aquarium cultures and inoculated in individual plastic flasks containing mineral water (1-cm high). After eclosion, the offspring that were presumably the most viable (based on 


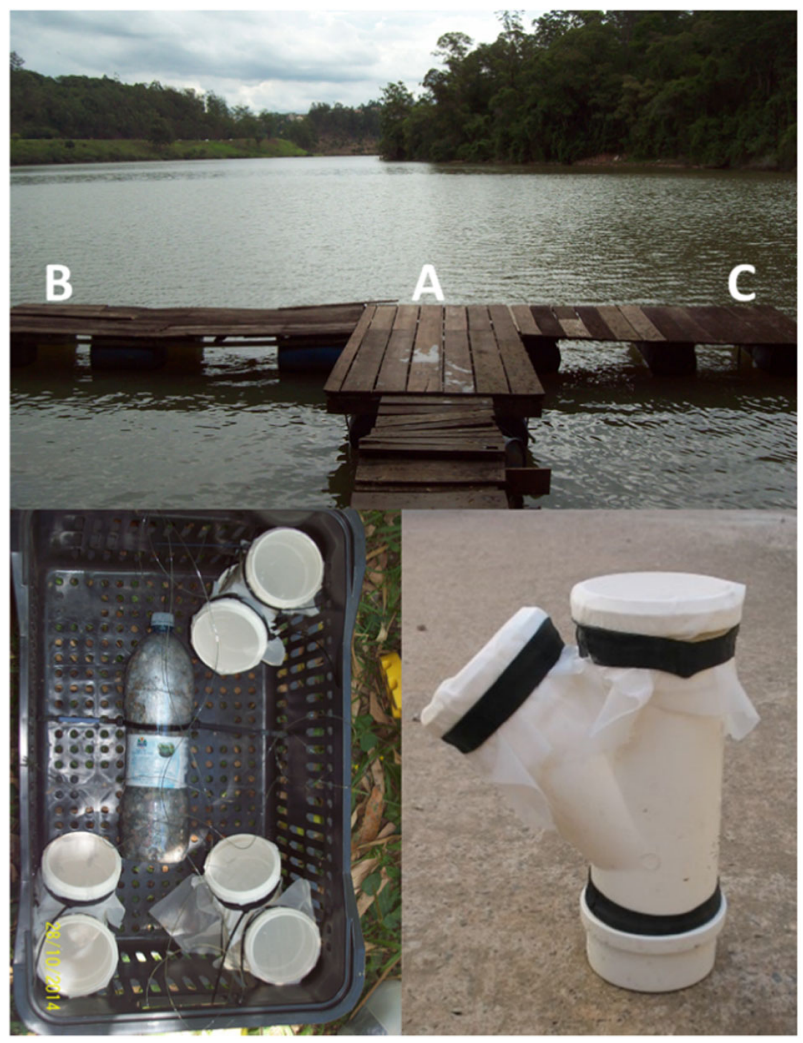

Fig. 3 Pictures showing stations A, B and C where cages were submerged, the experimental cage and an individual chamber where chironomid larvae where inoculated

movement and number of larvae) were separated to be used in the assays. A suspension of TetraMin Goldfish ${ }^{\circledR}$ (concentration $=0,04 \mathrm{mg} / \mathrm{L}$; volume $=25 \mathrm{~mL}$ ) was added every $48 \mathrm{~h}$ to the culture (Fonseca and Rocha 2004) containing the selected offspring until the larvae achieved the third instar.

Three cages $(30 \times 53 \times 33 \mathrm{~cm})$ were used in experiment. Chambers containing each of the three conditions (control, PC1 and PC2 sediments) were fixed in the cages, which were submerged in the reservoir. A bottle with stones was also fixed in the center of each cage to facilitate submersion and to avoid sudden movements caused by water fluctuation and flux. Each cage was tied to marginal trees by a nylon strip and submerged until it rested on the sediment bed (depth $=1.97 \pm 0.22$ m; Fig. 3 ).

The design of the chambers was based on Soares et al. (2005) with some modifications: we used PVC tubes with a "Y" shape $\left(45^{\circ}\right)$. In the bottom extremity, a PVC cover was fixed with an internal rubber "o" ring. The other two extremities were covered by $0.2 \mathrm{~mm}$ mesh. The mesh pieces were held in place with nylon on the inside of the chamber and a rubber strip on the outside of the chamber. Such a design allows the flux of water and the exchange of small particles and organisms with the environment but prevents the experimental larvae from escaping to the external environment.
The chambers had the following dimensions: $8.0 \mathrm{~cm}$ internal diameter, $22.5 \mathrm{~cm}$ height of the main arm and 12.0 $\mathrm{cm}$ length of the aslope arm. On the day before larvae were inoculated in the chambers, the sediments (treatments) were added until they were $2.0 \mathrm{~cm}$ high. Considering that chambers in the present work were larger than those used by Faria et al. (2006), the amount of food was adjusted to 60 $\mathrm{mg}$ of fish food instead of the $30 \mathrm{mg}$ originally recommended by Faria et al. (2006); this was done as a preventive measure to avoid false positives that could appear as length reductions caused by nutritional deficiencies.

The control sediments were quartz substrata (grain size $\approx$ $0.2 \mathrm{~mm}$ ), previously washed with distilled water and calcinated at $440^{\circ} \mathrm{C}$. The substrata composition was adopted for control conditions (i.e., soft sand with Tetramin fish food) and was similar to those suggested by Fonseca and Rocha (2004) when testing the ideal laboratorial conditions for culturing $C$. sancticaroli.

On 22 December 2014, five third-instar larvae were randomly chosen and inoculated in each chamber (treatment). The cages contained three chambers, with five larvae per chamber (total larvae $=15$ per treatment), and were submerged in the littoral region of Paiva Castro Reservoir at 11 a.m. The margins of the area where the experiment was conducted were covered by original riparian forest. The region where the experiment occurred was located between the two sampling stations (PC1 and PC2) where sediments were previously collected. The selection of the inoculation station was based on the safety of the cultures, the accessibility and the degree of preservation of the margins to prevent the loss of cages and unnecessary stressful conditions on the organisms. Once the objective of the study was to isolate the effects of the sediments on the organisms, an intermediate location with similar water conditions to those in all chambers was preferred instead of testing on the original sampling stations. The instar development was determined by measuring the width of the head capsule (Fonseca and Rocha 2004).

The physico-chemical characterization was determined at the beginning and end of the experiment by measuring $\mathrm{pH}$, dissolved oxygen concentration, temperature and electrical conductivity; measurements were taken near the bottom by using a Horiba multiprobe. Depth was measured by using a graduated string. It was assumed that the water flow was the same in stations A, B and C because it is a continuum (see Fig. 3); thus, the initial condition was determined at the center of station "A", and the final conditions were determined in triplicate in each station (stations A, B and C).

\section{Sediment characterization}

The metallic elements $\mathrm{As}, \mathrm{Cd}, \mathrm{Cr}, \mathrm{Cu}, \mathrm{Ni}, \mathrm{Pb}$ and $\mathrm{Zn}$ were determined by acid digestion and ICP reading according to 
method 3050-b (US-EPA 1996). Dried samples were digested without sieving and in triplicate. The limits of quantification (Shrivastava and Gupta 2011) and apparent recovery (Burns et al. 2002) were calculated using Eqs. (1) and (2). The observed concentration for Eq. (2) was obtained from solutions prepared with 100, 2500 and 5000 $\mu \mathrm{g} / \mathrm{L}$, which were equivalent to 10,250 and $500 \mathrm{mg} / \mathrm{kg}$, respectively.

$10 s / \alpha$

$R^{\prime}=x(o b s) / x(r e f)$

For Eq. (1), $s$ is the standard deviation of ten blank readings, and $\alpha$ is the regression slope of the calibration curve. In Eq. (2), x (obs) is the observed value obtained from a solution prepared with ICP standard solution (SpecSol) and ultrapure water, while $\mathrm{x}$ (ref) is the theoretical value that must be read. The organic matter content was determined by calcination $\left(550^{\circ} \mathrm{C}, 1 \mathrm{~h}\right)$ and weighting according to the method described in Wetzel and Likens (2000). The granulometric composition was determined in triplicate by sieving $(0.212 \mathrm{~mm}$ opening) dry sediment and then subtracting the percentage of previously determined organic matter.

\section{Biological metrics}

After 7 days, the chambers were opened, and live larvae were collected. The larvae were preserved in a $70 \%$ ethylic alcohol solution. Permanent slides were mounted in Canada balsam medium (Synth) according to the methodology described in Epler (2001) with some adaptations.

The slides were carefully analyzed under a light microscope (Zeiss Axiovert, Scope A1) with $1000 \times$ magnification. The biological metrics considered in this work were mortality (MOR), morphological alterations of mentum (ALT), larvae length (L), cephalic capsule width (CAPS) and damage (the occurrence of ALT or MOR). Width and length measurements were determined by using an ocular micrometer. Mortality was determined by observation considering the absence of movement or the response to mechanic stimuli.

To determinate the occurrence of morphological alterations, larvae were analyzed in triplicate by the same observer. At this stage, the observer had no knowledge about the conditions to which each specimen was subjected. Morphological analyses were performed twice by first using $400 \times$ magnification and then using $1000 \times$ magnification. The following criteria were considered to differentiate a normal mentum from an altered condition: symmetry, comparison to other specimens from the control condition (Beghelli et al. 2016) and comparison to illustrations in the literature that reported normal or altered conditions
(Madden et al. 1992; Bird 1994; Groenendijk et al. 1998; Epler 2001; Park et al. 2010; Trivinho-Strixino 2011b; Odume et al. 2012). We used the term "alteration" instead the more common term "deformation" to emphasize that we were considering even slight differences in the mentum tooth, even reductions that are commonly neglected in studies with chironomids. Despite the argument that this type of morphological alteration is not very evident, we believe that it is important to investigate this conclusion, especially because other authors have reported this condition as a biological response to sediment pollution (Salmelin et al. 2015). By doing so, we assume that these alterations may be occur before more radical or stronger deformities, which are more commonly reported. From an overall view, these slight alterations may be considered as specific cases of morphological asymmetry.

\section{Data analyses and statistical procedures}

Data from environmental characterization $(\mathrm{pH}$, temperature, dissolved oxygen, electrical conductivity and depth) were standardized and analyzed using multivariate analysis (ANOSIM) to test the hypothesis that the environmental conditions in stations $\mathrm{A}, \mathrm{B}$ and $\mathrm{C}$ were similar.

The theoretical toxicity of each element per treatment was calculated in terms of toxic units (Sprague 1970), considering the reference values reported by the US-EPA (1999).

When multiple pollutants are present in the environment, it is difficult to distinguish between the isolated effects of each pollutant, especially when considering the possibility of interactions between them (Di Veroli et al. 2014); thus, the overall toxicity must be an acceptable and simple approach to test the toxicity of a substrate subjected to multiple stressors. The overall toxicity of treatments was determined by the sum of the theoretical toxicities of each element (Xiao et al. 2013). Only metals with TU $\geq 1$ (presumed toxic effects on biota) in at least one treatment were considered for statistical analyses.

For continuous biological data (L and CAPS), two-way ANOVA tests using a block experimental design were performed to verify if treatments (CTRL, PC1 and PC2 sediments) and different experimental stations affected chironomid larvae. Binary responses of morphological alterations, mortality and damage were compared to a logistic curve by a post hoc analysis of deviances (Logan 2010).

Considering the toxicity of sediments and the previous data indicating metal pollution in sediments of PC1 and $\mathrm{PC} 2$, as well as the evidence of effects on benthic macroinvertebrates (Beghelli et al. 2014; Beghelli et al. 2016; Cardoso-Silva et al. 2016), this work tried to isolate the effects of natural sediments on a unique benthic species. We 
hypothesized that sediments from $\mathrm{PC} 1$ and $\mathrm{PC} 2$ (reported as probably polluted by metals, $\mathrm{PC} 1<\mathrm{PC} 2$ ) induced biological effects on chironomid larvae. From this main hypothesis, more specific hypotheses emerged as follows:

1. The proportion of mouthpart alterations must increase in the order CTRL-PC1-PC2.

2. Average larval length must decrease in the order CTRL-PC1-PC2.

3. Head capsule width may not vary significantly among treatments.

4. The occurrence of deaths must increase in the order CTRL-PC1-PC2.

5. Total damage occurrence (i.e., death or mouthpart alteration) must increase in the order CTRL-PC1-PC2.

\section{Results}

\section{Experimental conditions}

\subsubsection{Physico-chemical conditions}

The initial condition of station " $\mathrm{A}$ " and the average values at each station at the end of the experiment are shown in Table 3. There was no significant variation among stations $(p=$ 0.18 )

Sediments from PC1 and PC2 had lower proportions of coarse fraction $(>0.212 \mathrm{~mm})$ than the sediments in the control. Similar percentages of organic matter were verified in samples from PC1 and PC2 (Fig. 4).

Sediment composition was significantly distinct in relation to grain size $(p<0.05)$. Both treatments (PC1 and PC2) presented similar organic matter compositions $(p>0.05)$ but were significantly different from the control condition.

Table 3 Physico-chemical characterization of the inoculation environment: depth, temperature, $\mathrm{pH}$, electrical conductivity (EC), dissolved oxygen (DO)

\begin{tabular}{llllll}
\hline & \multicolumn{3}{l}{ 1st day } & 7th day \\
\hline Station & - & A & A & B & C \\
Depth $(\mathrm{m})$ & - & 2.0 & 2.0 & 2.2 & 1.7 \\
$\mathrm{~T}\left({ }^{\circ} \mathrm{C}\right)$ & Average & 23.76 & 27.70 & 27.46 & 27.89 \\
& $s$ & - & 0.01 & 0.55 & 0.27 \\
$\mathrm{pH}$ & Average & 5.63 & 5.25 & 5.25 & 5.58 \\
& $s$ & - & 0.07 & 0.05 & 0.46 \\
$\mathrm{EC}(\mu \mathrm{S} / \mathrm{cm})$ & Average & 41.00 & 42.00 & 42.60 & 42.00 \\
& $s$ & - & 0.00 & 0.00 & 0.00 \\
$\mathrm{DO}(\mathrm{mg} / \mathrm{L})$ & Average & 6.16 & 6.05 & 5.86 & 10.10 \\
& $s$ & - & 0.51 & 0.54 & 0.72 \\
\hline
\end{tabular}

\section{Metal analysis and theoretical toxicity}

The overall toxicity (Table 4) increased in the order CTRL $<\mathrm{PC} 1<\mathrm{PC} 2$. Only the metallic elements $\mathrm{Cr}, \mathrm{Cu}$ and $\mathrm{Ni}$ were considered as potentially toxic (i.e., $\mathrm{TU} \geq 1$ ). As expected, there were no toxicity records in the control treatment. $\mathrm{Cu}$ had the most toxic concentration measured in the sediments.

\section{Biological variables}

The width of the head capsule after the 7-day experiment ranged between 0.26 and $0.58 \mathrm{~mm}$ (average $=0.45 \pm 0.11$ ). This result indicates that many of the inoculated larvae reached the last larval instar (Fonseca and Rocha 2004). One pupa was recovered.

Larvae collected from chambers with the PC2 treatment achieved an average length of $4.48 \mathrm{~mm}$; in contrast, larvae collected from chambers with the control conditions achieved an average length of $9.42 \mathrm{~mm}$. This computes to a difference of $4.94 \mathrm{~mm}$ (i.e., $110.26 \%$ of the average length recorded in PC2) when comparing the most favorable conditions to the worst conditions considered in this work.

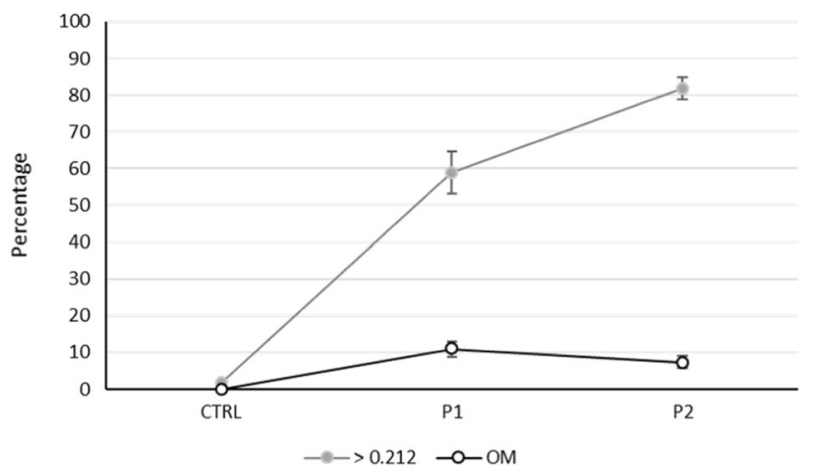

Fig. 4 Sediment grain size composition $(\mathrm{mm})$ and organic matter percentage

Table 4 Metal concentrations in experimental sediments $(\mathrm{mg} / \mathrm{kg})$ and theoretical toxicity values (TU). Elements with no toxicity records are not shown

\begin{tabular}{llllll}
\hline \multicolumn{1}{c}{} & & $\mathrm{Cr}$ & $\mathrm{Cu}$ & $\mathrm{Ni}$ & $\sum \mathrm{TU}$ \\
\hline Concentration & Control & 3.12 & $<\mathrm{LQ}$ & $<\mathrm{LQ}$ & - \\
& & $( \pm 0.39)$ & & & \\
& $\mathrm{PC} 1$ & 25.99 & 26.51 & 12.67 & - \\
& & $( \pm 0.57)$ & $( \pm 0.65)$ & $( \pm 0.09)$ & \\
\multirow{5}{*}{ Toxicity } & $\mathrm{PC} 2$ & 36.98 & 46.59 & 35,87 & - \\
& & $( \pm 1.58)$ & $( \pm 0.56)$ & $( \pm 1.13)$ & \\
& Control & 0.1 & 0.0 & 0.0 & 0.3 \\
& PC1 & 1.0 & 1.7 & 1.1 & 3.8 \\
& PC2 & 1.4 & 2.9 & 2.2 & 6.6 \\
\hline
\end{tabular}


Mortality ranged from 60 to $73 \%$, while the incidence of morphological alterations varied from $33.33 \%$ in larvae recovered from chambers with control treatments to $100 \%$ in larvae from PC2 conditions. The most common

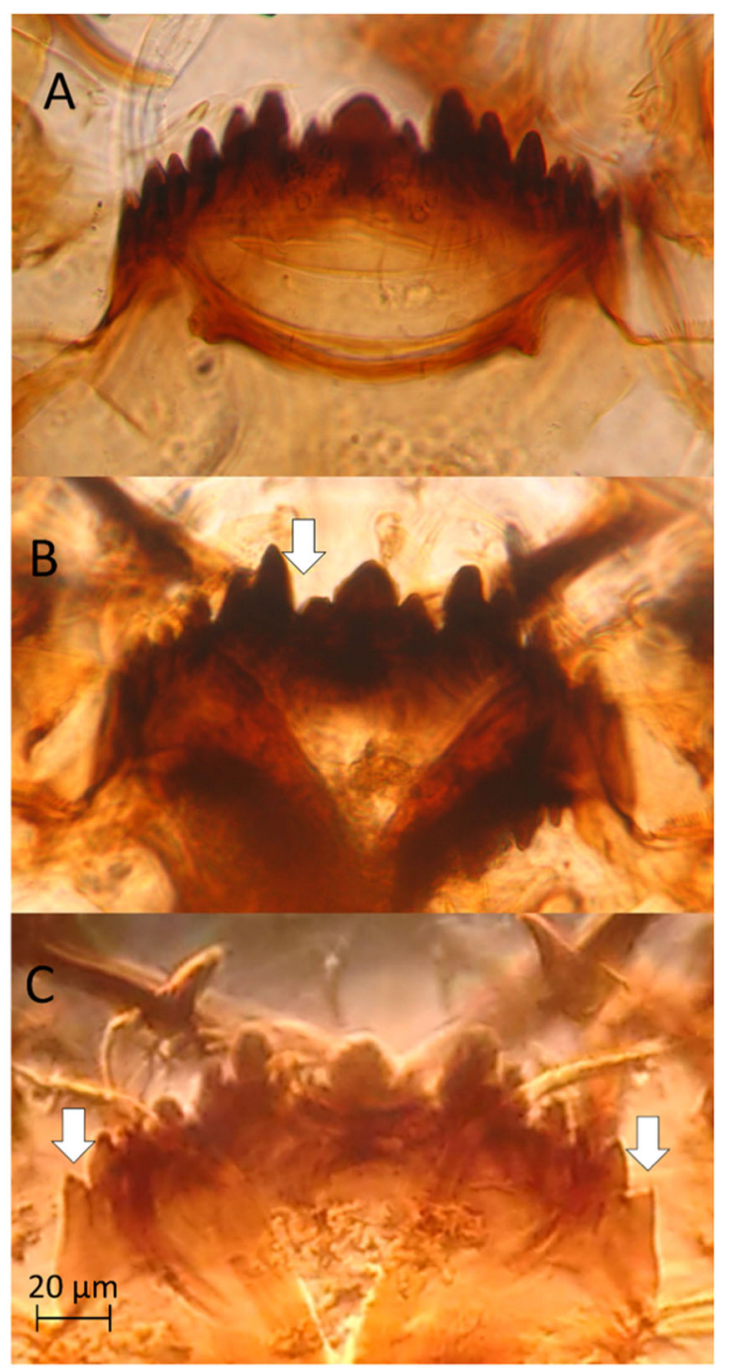

Fig. 5 A normal mentum from a specimen recovered from the CTRL condition $\left(\mathrm{A}, \sum \mathrm{TU}=0.3,>0.212=1.8 \%, \mathrm{OM}=0.02 \%\right)$. An altered mentum with a reduced mid-lateral tooth from a specimen recovered from the PC1 treatment $\left(\mathrm{B} ; \sum \mathrm{TU}=3.8 ;>0.212=78.8 \%\right.$; $\mathrm{OM}=$ $10.9 \%)$. A mentum with reduced outer lateral teeth from a specimen recovered from the $\mathrm{PC} 2$ treatment $\left(\mathrm{C} ; \sum \mathrm{TU}=6.6 ;>0.212=81.8 \%\right.$; $\mathrm{OM}=7.4 \%$ ) morphological alteration was the reduction of one or more teeth in the mentum (Fig. 5).

Information on the occurrence of the biological variables ALT, MOR and DAM and the measures of L and CAPS with the respective sample sizes $(n)$ and statistical populations $(N)$ are shown in Table 5.

\section{Biological responses}

Biological data responded to treatments (CTRL, PC1 and PC2), but there were no observable effects caused by the experimental stations (A, B and C) on test organisms. The average larval body length reduced in the order CTRL-PC1PC2 (i.e., with increasing sediment toxicity). However, the width of head capsules did not present significant variation among the treatments (Fig. 6).

Considering the binary biological data (MOR, ALT and DAM), only the differences in the total damage occurrence were statistically significant $(p<0.05)$. Chambers with the most toxic sediments (PC2) presented a higher incidence of damage.

A similar percentage of deaths was recorded in the control and PC1 treatment. In general, chambers with sediments from PC2 presented higher mortalities, but the differences were not significant. The proportion of mouthpart alterations (ALT) per treatment also increased with the increase in sediment toxicity. However, the relation could not be considered statistically significant (Fig. 7, Table 6).

\section{Discussion}

The results obtained agreed with those that suggest $C$. sancticaroli is a good bioindicator of sediment pollution in South America. This organism is recommended for assays or biomonitoring (Moreira-Santos et al. 2005; Printes et al. 2011) instead of other Chironomus species typical of temperate regions (usually $C$. riparius) when the objective is to understand the ecosystem status. Despite the availability of other test organisms, such as $C$. riparius, a native species like $C$. sancticaroli is adapted to the specificities of tropical ecosystems, which may include higher temperatures, lighting and productivity; distinct patterns of water circulation;

Table 5 Frequency of occurrence of mouthpart alterations (ALT), death (MOR) and damage (DAM = ALT + MOR). Body length (L) and width of head capsules (CAPS)

\begin{tabular}{llllll}
\hline & ALT & MOR & DAM & L & CAPS \\
\hline Control & $2(n=6)$ & $9.00(n=15)$ & $11(n=15)$ & $9.42(n=6)$ & $0.50(n=6)$ \\
PC1 & $4(n=5)$ & $9.00(n=15)$ & $13(n=14)$ & $8.26(n=5)$ & $0.54(n=5)$ \\
PC2 & $3(n=3)$ & $11.00(n=15)$ & $14(n=15)$ & $4.48(n=3)$ & $0.43(n=3)$ \\
$N$ & 14 & 45 & 44 & 14 & 14 \\
\hline
\end{tabular}




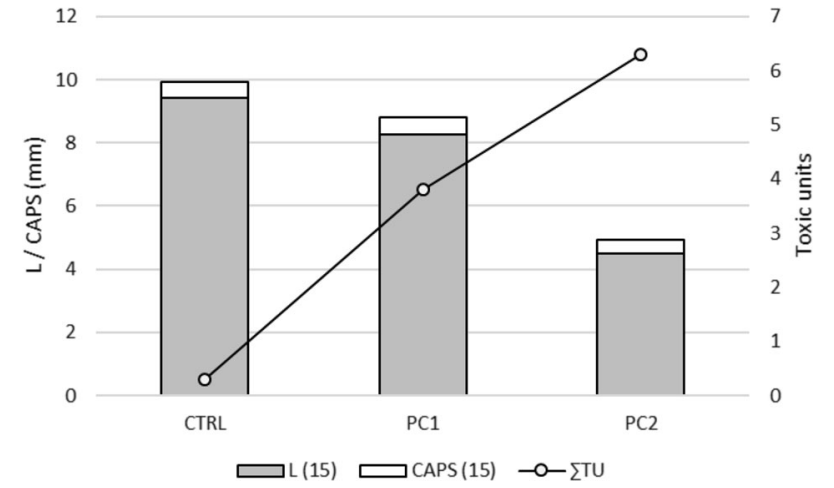

Fig. 6 Chart showing average larval length (L) and head capsule width (CAPS) (mm) among treatments (CTRL, PC1 and PC2), indicating the general toxicity $\left(\sum \mathrm{TU}\right)$ at each condition

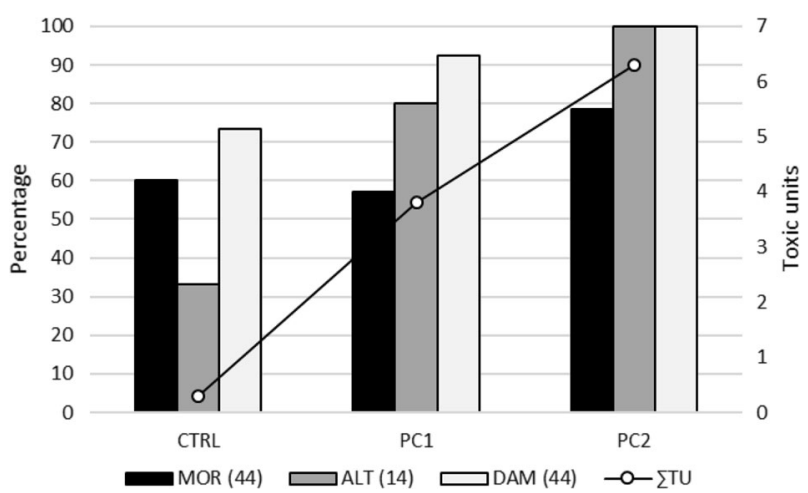

Fig. 7 Chart showing the percentage (referring to the entire experiment per treatment) of deaths (MOR); morphological alterations (ALT) and occurrence of damage (DAM). Numbers in parentheses indicate sample size. Points show the overall toxicity of metals in sediments as toxic units $\left(\sum \mathrm{TU}\right)$

Table 6 ANOVA and analysis of deviance results considering differences between stations or treatments (TREAT)

\begin{tabular}{lllll}
\hline & L (15) & CAPS (15) & MOR (44) & ALT (14) \\
\hline STATION & 0.899 & 0.071 & 0.089 & 0.194 \\
TREAT & $\mathbf{0 . 0 1 8}$ & 0.074 & 0.464 & 0.061 \\
\hline
\end{tabular}

Values in bold are statistically significant

higher decomposition rates and organic matter deposition (Tundisi and Matsumura 2008), and C. sancticaroli can provide responses that will be more realistic in those systems (Nikinmaa 2014).

Our results complement previous attempts to establish methodology and standards for biomonitoring with $C$. sancticaroli (Moreira-Santos et al. 2005; Dornfeld et al. 2006; Santos et al. 2007; Janke et al. 2011; Printes et al. 2011 and Campagna et al. 2013, Richardi et al. 2015). The present experiment also contributed to the establishment of simple solutions with low costs of biomonitoring by using in situ assays to complement previous works (Soares et al. 2005; Dornfeld et al. 2006; Faria et al. 2006).

Despite the apparently high mortality in control conditions as compared to laboratorial assays, where survival expectance is between 90-95\% (Fonseca and Rocha 2004), the in situ experiment developed here was successful. A mortality rate of $60 \%$ may be acceptable for in situ assays with $C$. sancticaroli when considering the wider range of stressful conditions that larvae may be exposed to (Dornfeld et al. 2006).

The comparatively high mortality in this assay must be related to synergistic effects (Dornfeld et al. 2006) that are common in impaired environments (Di Veroli et al. 2012). Furthermore, deaths in the control condition are probably related, at least in part, to water pollution. Available data indicate that pollution by the metals $\mathrm{Al}$ and $\mathrm{Fe}$ reached concentrations that were considered as probable to adversely affecting biota (CCME 2014).

The concentrations of $\mathrm{Al}$ and $\mathrm{Fe}$ in water may have equally affected every treatment and may have contributed to increasing mortality even in control conditions. Previous data indicate that, at minimum, aluminum is an important factor that can reduce Chironomus survival. In a chronic assay with C. riparius larvae, Cardwell et al. (2018) reported adverse effects on larval growth in treatments with 2.13-4.28 $\mu \mathrm{g} \mathrm{Al} / \mathrm{L}$. These values are many times lower than those recorded here $(480-640 \mu \mathrm{g} \mathrm{Al} / \mathrm{L})$. In terms of iron toxicity, despite CCME assertions that iron concentrations of $300 \mathrm{mg} / \mathrm{L}$ are high enough to cause adverse effects in biota, Chironomus larvae may be more resistant. For example, Rousch et al. (1997) did not record any effects on survival in $C$. riparius larvae that had been included in treatments with Fe concentrations lower than $400 \mathrm{mg} / \mathrm{L}$. The concentrations of iron in water reported from Paiva Castro are many times lower than this threshold and must not be a factor directly contributing to mortality. Considering that it is an in situ assay where all chambers were submerged in the same region, each replicate was subjected to similar water conditions, and the differences among treatments can be strictly attributed to sediment conditions. It is also necessary to understand that the values reported here for metallic ions in water must be considered as an approximation rather than as an exact measure because they came from samples collected prior to inoculation.

The experimental design adopted here was designed to test if the sediments can induce biological responses in natural conditions; however, the design was not adequate to separate the effects of each variable. Considering this, despite the fact that the results clearly indicated a toxic effect by metals, which was measured in terms of general toxicity, if we suppose there was an additive effect of the metals above TRV, it is probable that the sediment composition (in relation to organic matter and clay content) 
affects toxicity through the complexation and adsorption mechanisms (Demirak et al. 2012; Martins et al. 2015) that are associated with the ecological traits of Chironomus larvae, which construct sediment tubes (Fonseca and Rocha 2004) and ingest organic particles (Henriques-Oliveira et al. 2003). However, it was not possible to distinguish these effects with the adopted experimental design.

Furthermore, in situ experiments have multiple natural and anthropic variables that cannot be controlled at all. In addition, natural sediments are complex elements composed of organic and inorganic material that comes from various sources that can be natural or anthropic (Guo and Yang 2016). As a result, the presence of other pollutants (mainly agrochemicals and organic pollutants from sewage discharge) that were not considered here may also interfere with the observable effects.

Our results indicate similar conditions in terms of the percentage of organic matter in PC1 and PC2 (next to 10\%) but an increasing percentage in soft inorganic sediment in the same order as metal toxicity: CTRL-PC1-PC2. Generally, the finest sediment fractions (i.e., clay and silt) tend to accumulate metals that can be adsorbed to them. The same can be said about organic matter, which frequently forms complexes with metals in aquatic environments (Hart 1982). To understand sediment toxicity, both the physicochemical properties and the biological habits of each species must be considered. Chironomus larvae are burrowing collectors; they build sediment tubes and ingest organic matter particles. These characteristics will increase the exposure of Chironomus larvae to metals in environments with a high proportion of organic matter and silt-clay particles in the sediments.

In terms of the toxicity of sediments in Paiva Castro, the results obtained here complement the evidence obtained in field studies from the Cantareira Complex that relate the metal pollution in sediments with biological responses (Beghelli et al. 2014; Beghelli et al. 2016). According to the US-EPA (1999) threshold reference values, the sediments from PC1 and PC2 that were analyzed here could be classified as toxic because of the measured $\mathrm{Cr}, \mathrm{Cu}$ and $\mathrm{Ni}$ concentrations $(T U \geq 1)$. Even so, it was observed that metal concentrations in sediments increased from 2013 to 2014, probably as a result of an unusual drought that occurred in São Paulo State in 2014 and forced the use of the dead water reserve by SABESP (the autarchy that controls the water supply to the Metropolitan Region of São Paulo) on May 16th, 2014 (Leite 2014; SABESP 2017).

As a field study, previous work (Beghelli et al. 2016) could not categorically assert whether the observed alterations were actually a consequence of sediment toxicity. Furthermore, field studies have another source of variability, i.e., the faunal diversity. The entire Chironomidae family was considered in that study. Taking previous work into consideration, the present in situ research contributed new information by reducing the number of predictor variables (the only variable was sediment composition; water and locality were the same across treatments) and biological interferences (using the same offspring minimized biological variability).

The morphological alterations observed in this study were mainly cases of minor severity (Grebenjuk and Tomilina 2014) that were similar to the most common previously recorded alterations (Beghelli et al. 2016). Warwick (1988) apud Warwick and Tisdale (1998) determined "a morphological structure is considered deformed if its configuration departs from the normal". The authors recognized that this is a broad definition, and the exact problem was defining what was considered to be "normal" (Warwik and Tisdale 1998). Apparently, there is still no consensus in this respect (Salmelin et al. 2015).

Despite more conservative authors adopting the position to not consider slight morphological alterations as abnormalities because they can lead to misinterpretations or can be related to other conditions that are not of interest in biological monitoring (Salmelin et al. 2015), e.g., broken teeth during slide preparation, effects of sediment grain composition (Bird 1996) and inbreeding (Vogt et al. 2012), we are of the opinion that, despite difficulties, these data must be considered in order to contribute to the definition of what is considered the "normal" condition versus what is considered a response to stressful conditions with a lower "limit of detection". We believe that the procedure adopted here, which used blind replicates in morphological analysis and considered the criteria of symmetry and comparison with larvae from the control, may be sufficient to reduce the errors that may have greater impacts on the interpretation of data.

Regardless, the hypotheses related to morphological alterations and mortality could not be confirmed in the present research. However, when considering the entire experimental population, some trends may be perceived (Fig. 7). The proportion of mouthpart alterations actually increased with toxicity, but variability was high in relation to sample sizes. It is also very probable that high mortality had a strong effect on this result and reduced the sample size, which led us to believe that, in tests with lower mortality (e.g., laboratorial assays), larger sample sizes (i.e., number of replicates) or larger ranges of toxicity, this effect could be observed more clearly.

Bisthoven and Ollevier (1998) worked with field data and confirmed the bioindicator potential of morphological alterations in $C$. riparius larvae by relating these deformities as a probable response to $\mathrm{Cu}$ concentrations in water and $\mathrm{Pb}$ concentrations in sediments; in contrast, Beghelli et al. (2016) recorded morphological alterations in chironomid larvae belonging to different species from the Cantareira 
Complex, i.e., the complex of reservoirs that includes Paiva Castro Reservoir, which was considered in the present work.

Another point that must be considered is the percentage of alterations recorded in the control conditions. In the present work, the percentage of observed alterations in the control conditions was $33 \%$. Some authors consider background frequencies of abnormalities to be those lower than 8\% (Warwik and Tisdale 1998; Lotfi et al. 2016). However, frequencies higher than $20 \%$ have been reported in nonimpaired conditions (Bird 1996; Di Veroli et al. 2012). These last results are more consistent with ours, indicating that divergences must be determined using the concept of what is "normal" in research. Furthermore, the frequency of alterations in the control conditions of the present work is quite similar to that predicted by the linear model proposed by Beghelli et al. (2016), i.e., $25.36 \%$ in the absence of the effects of $\mathrm{Cu}$ pollution in sediments of the Cantareira Complex, indicating some consistency of the method in respect to what is considered to be a morphological alteration.

Di Veroli et al. (2012) subjected C. riparius larvae to sediments polluted by a mixture of the metals $\mathrm{Cd}, \mathrm{Cr}, \mathrm{Cu}$, $\mathrm{Ni}, \mathrm{Pb}$ and $\mathrm{Zn}$ in increasing concentrations. They recorded the correlation between morphological alterations and overall toxicity in spiked sediments but not in natural sediments. The authors attributed this difference to the probable presence of other pollutants in the natural sediments based on the high incidence of morphological alterations even when metal concentrations were relatively low. The authors recorded a rate of morphological alterations of approximately $25 \%$ in larvae treated with natural sediments from a "non-polluted" area. As a result, we hypothesize that the $33 \%$ of mouthpart alterations recorded here may be mainly due to the presence of other pollutants in the water, and we also recognize that some inbreeding effect from the larval culture may also be present (Salmelin et al. 2015).

Comparing these results with data shown here, we can hypothesize the following: apparently, the toxicity of sediments are the main environmental factor driving the proportion of mouthpart alterations and the occurrence of deaths. However, toxicity in sediments from Paiva Castro Reservoir may not be sufficiently high enough to distinguish using the adopted experimental design, especially in terms of the toxicity range and mortality. By analyzing Fig. 7 , it can be seen that some distinction starts in the conditions present in sediments from PC2, where toxicity was approximately 6 TU. However, this threshold cannot be categorically assumed $(p>0.05)$, and future experiments may confirm or deny this trend.

In this case, by considering the biological measure of the occurrence of damage, we could assess the biological responses without being affected by the losses of dead organisms; this is in contrast to the situation where only ALT can be considered because dead larvae could not be recovered, and the occurrence of morphological alterations could not be confirmed in such cases.

In this line of thinking, it is plausible to assume that the sublethal effect (ALT) is a consequence of environmental stress conditions that are not strong enough to increase the mortality rate. However, the sublethal effect can cause a biological response that can result in death as the environmental disturbance increases. By considering the occurrence of damage, this biological continuum can be assessed, and it is naturally more sensitive than mortality (Martinez et al. 2002).

The observed effects on larval length and the occurrence of total damage could be clearly related to the overall toxicity of sediments. Considering that every specimen analyzed here came from the same offspring, and that the cages were submerged in the same environment, it can be stated that variations among treatments must be attributed mainly to sediment characteristics. Statistical analyses confirmed the absence of effects related to the experimental stations (i.e., the small variations in location, water characteristics and depth as well as aleatory effects were not significant).

Another biological endpoint frequently considered in bioassays with Chironomus larvae is body length (Faria et al. 2006; Campos et al. 2016). Measures of body length must be altered as a consequence of toxicity in the environment, even when death does not occur. One plausible explanation is that the organisms must spend more energy to live in stressful conditions, and as a consequence, there will be less energy available for larval growth (Du et al. 2014). For example, the data from an in situ assay performed by Kellar et al. (2014) indicated the effects of pesticides and metal pollution on larval growth and emergence but not on mortality, indicating that there were sublethal toxicity levels capable of compromising the development of the organisms. A similar situation was verified from our data.

Although all treatments were prepared with sufficient food to prevent false-positive results, we recognize that organic matter content may favor larval growth in Chironomus species (Faria et al. 2006). In this respect, Lacey et al. (1999) demonstrated that organic matter in sediments had important influences on growth and could affect the results of bioassays with Chironomus. In addition, organic matter is an important environmental factor that regulates the distribution of metals (Martins et al. 2015).

\section{Conclusions}

We presented a successful and easy-to-apply in situ assay using a native species from South America, and we 
demonstrated that it can be successfully used to monitor sediment toxicity caused by metal pollution. The design of the cages presented here prevents problems caused by using any kind of glue that could generate some additional toxicity.

The present study demonstrated that this test can be associated with field data to isolate sediment effects in natural conditions, which provides more accurate results for monitoring conclusions and avoids variations associated with biological diversity, location and water characteristics.

The results align with previous data from Beghelli et al. (2014) and reinforce the idea that sediments from Paiva Castro are polluted by metallic elements. The present work also complemented previous research in the Cantareira Complex that highlighted the adverse effects of sediments on benthic macroinvertebrates. We isolated the effects of sediments and experimentally demonstrated that sediments from Paiva Castro truly can affect benthic organisms, which presented observable responses (i.e., sublethal effects) to treatments in relation to total damage and larval length. Overall metal toxicity in sediments ranged from 0 to $6.6 \mathrm{TU}$ and was not apparently lethal to $C$. sancticaroli larvae. To clarify the relationship between the morphological alterations recorded here and the sediment toxicity, further research using other experimental designs should be conducted.

Data from this experiment are complementary to those from Dornfeld et al. (2006) and Moreira-Santos et al. (2005) in the sense that in situ assays with $C$. sancticaroli are recommended for biomonitoring in tropical regions. Currently, the geographical distribution of this chironomid is restricted to Argentina and Brazil (Fonseca and Rocha 2004). The ideal organism for biomonitoring would be a native species, but considering the similarities of tropical ecosystems and the scarcity of tropical species studied for bioassays (Nikinmaa 2014), the use of $C$. sancticaroli is recommended for biomonitoring in other tropical environments, and it is equally recommended for developing monitoring procedures that could follow similar procedures adopted here using other chironomid species in specific regions.

Acknowledgements We are thankful to Susana Trivinho-Strixino (Ph.D.) for her dedication and collaboration in reading and suggesting improvements for this work. We also thank Daniel Gomes for offering his property and installations for use during field work. The authors thank the Fundação de Amparo à Pesquisa do Estado de São Paulo, FAPESP (process numbers 2012/11890-4, 2012/16420-6, 2013/03494-4, 2013/08272-0 and 2014/22581-8) for its financial support.

Funding This study was funded by the Fundação de Apoio à Pesquisa do Estado de São Paulo (grant numbers 2012/11890-4, 2012/16420-6, 2013/03494-4, 2013/08272-0 and 2014/22581-8).

\section{Compliance with ethical standards}

Conflict of interest The authors declare that they have no conflict of interest.

Ethical approval All applicable international, national, and/or institutional guidelines for the care and use of animals were followed.

\section{References}

Beghelli FGS, Pompêo MLM, Watanabe CH, Rosa AH, MoschiniCarlos V (2014) Caracterização e análise de metais nos sedimentos da região litorânea de represas do Sistema Cantareira/SP. In: Rino, CAF (ed.) (coord). Anais do V Congresso Brasileiro de Gestão Ambiental. Belo Horizonte, MG, pp. VIII 1-5. http:// www.ibeas.org.br/congresso/anais.htm

Beghelli FGS, Pompêo MLM, Rosa AH, Moschini-Carlos V (2016) Effects of copper in sediments on benthic macroinvertebrate communities in tropical reservoirs. Limnetica 35:103-116

Betinetti R, Ponti B, Marziali R, Rossaro B (2012) Biomonitoring of lake sediments using benthic macroinvertebrates. Trends Anal Chem 36:92-102

Bird GA (1994) Use of chironomid deformities to assess environmental degradation in the Yamaska river, Quebec. Environ Monit Assess 30:163-175

Bird GA (1996) Deformities in cultured Chironomus tentans larvae and the influence of substrate on growth, survival and mentum wear. Environ Monit Assess 45:273-283

Bisthoven LJ, Ollevier AVF (1998) Experimental induction of morphological deformities in Chironomus riparius larvae by chronic exposure to copper and lead. Arch Environ Contam Toxicol 35:249-256

Burns DC, Danzer K, Townshend A (2002) Use of the terms "recovery" and "apparent recovery" in analytical procedures. Pure Appl Chem 74:2201-2205

Campagna AF, Rogdrigues BK, Nogueirol RC, Verani NF, Espíndola ELG, Alleoni LRF (2013) Use of artificial sediment to assess toxicity of chromium on Chironomus xanthus, Danio rerio and Poecilia reticulate. Acta Limnol Braz 25(1):42-53. https://doi. org/10.1590/S2179-975X2013000100006

Campos D, Gravato C, Quintaneiro C, Soares AMVM, Pestana JLT (2016) Responses of the aquatic midge Chironomus riparius to DEET exposure. Aquat Toxicol 172:80-85

Canadian Council of The Ministers of The Environment (CCME) (2001) Canadian sediment quality guidelines for the protection of aquatic life. http://ceqg-rcqe.ccme.ca/en/index.html\#void. Accessed 24 July 2017

Canadian Council of the Ministers of the Environment (CCME) (2014) Water quality guidelines for the protection of the aquatic life. http://ceqg-rcqe.ccme.ca/en/index.html\#void. Accessed 24 July 2017

Cardoso-Silva S, Ferreira PAL, Moschini-Carlos V, Figueira RCL, Pompêo M (2016) Temporal and spatial accumulation of heavy metals in the sediments at Paiva Castro Reservoir (São Paulo, Brazil). Environ Earth Sci 75:9-25

Cardwell AS, Adams WJ, Gensemer RW, Nordheim E, Santore RC, Ryan AC, Stubblefield WA (2018) Chronic toxicity of aluminum, at a $\mathrm{pH}$ of 6, to freshwater organisms: Empirical data for the development of international regulatory standards/criteria Environ Toxicol Chem 37:36-48

Companhia Ambiental do Estado de São Paulo - CETESB (2015) Qualidade das águas superficiais no estado de São Paulo 2014. CETESB, São Paulo. São Paulo, Brasil. http://cetesb.sp.gov.br/a guas-interiores/wp-content/uploads/sites/12/2013/11/Cetesb_Qua 
lidadeAguasSuperficiais2014_ParteI_vers\%C3\%A3o2015_Web. pdf. Accessed 24 July 2017

Companhia de Saneamento Básico do Estado de São Paulo SABESP. Governo do Estado e Sabesp iniciam captação de água da reserva técnica do Cantareira. http://site.sabesp.com.br/ imprensa/noticiasdetalhe. aspx $?$ secaold $=66 \mathrm{eid}=6245$. Accessed 24 July 2017

Cortelezzi A, Paggi AC, Rodríguez M, Capítulo AR (2011) Taxonomic and nontaxonomic responses to ecological changes in an urban lowland stream through the use of Chironomidae (Diptera) larvae. Sci Total Environ 409:1344-1350

Demirak A, Yılmaz HA, Keskin F, Sahin Y, Akpolat O (2012) Investigation of heavy metal content in the suspended particulate matter and sediments of inner Gokova Bay and creeks. Environ Monit Assess 184(12):7113-7124

Di Veroli A, Goretti E, Paumen ML, Kraak MHS, Admiraal W (2012) Induction of mouthpart deformities in chironomid larvae exposed to contaminated sediments Environ Pollut 166:212

Di Veroli A, Santoro F, Pallottini M, Selvaggi R, Scardazza F, Cappelletti D, Goretti E (2014) Deformities of chironomid larvae and heavy metal pollution: from laboratory to field studies. Chemosphere 112:9-17

Dornfeld CB, Espíndola ELG, Fracácio R, Novelli LA (2006) Comparação de Bioensaios Laboratoriais e "in situ" utilizando Chironomus sancticaroli na avaliação da toxicidade de sedimentos do Rio Monjolinho (São Carlos, SP). J Braz Soc Ecotoxicol $1: 161-165$

Du J, Li Y, Huang ZC, You J (2014) Chronic toxicity thresholds for sediment-associated benzo[a]pyrene in the bidge (Chironomus dilutus). Arch Environ Contam Toxicol 66:370-378

Duffus JH (2002) "Heavy metals" - A meaningless term? (IUPAC technical repport). Pure Appl Chem 74:793-807

Epler JH (2001) Identification manual for the larval Chironomidae (Diptera) of North and South Carolina. North Carolina Department of Environment and Natural Resources. https://files.nc.gov/ ncdeq/Water\%20Quality/Environmental\%20Sciences/BAU/ Benthos\%20Reference/intro.pdf. Accessed 04 December 2017

Faria MS, Ré A, Malcato J, Silva PCLD, Pestana J, Agra AR, Nogueira AJA, Soares AMVM (2006) Biological and functional responses of in situ bioassays with Chironomus riparius larvae to assess river water quality and contamination. Sci Total Environ 371:125-137

Fonseca AL, Rocha O (2004) Laboratory cultures of native species Chironomus sancticaroli Strixino \& Strixino, 1981 (DipteraChironomidae). Acta Limnol Bras 16:153-161

Groenendijk D, Zeinstra LWM, Postma J (1998) Fluctuating asymmetry and mentum gaps in populations of the midge Chironomus riparius (Diptera: Chironomidae) from a metal contaminated river. Environ Toxicol Chem 17:1999-2005

Grebenjuk LP, Tomilina II (2014) Morphological deformations of hard chitinized mouthpart structures in larvae of the genusChironomus (Diptera, Chironomidae) as the Index of Organic Pollution in Freshwater Ecosystems. Inland Water Biol 7:79-91

Guo Y, Yang S (2016) Heavy metal enrichments in the Changjiang (Yangtze River) catchment and on the inner shelf of the East China Sea over the last 150 years. Sci Total Environ 543:105-115

Hart BT (1982) Uptake of trace metals by sediments and suspended particulates: a review. Hydrobiol 91:299-313

Henriques-Oliveira AL, Nessimian JL, Dorvillé LFM (2003) Feeding habits of Chironomid larvae (Insecta: Diptera) from a stream in the Floresta da Tijuca, Rio de Janeir, Brazil. Brazilian J Biol. https://doi.org/10.1590/S1519-69842003000200012

Janke H, Yamada TM, Berando DAS, Botta CMR, Nascimento MRL, Mozeto AA (2011) Assessment of the acute toxicity of eutrophic sediments after the addition of calcium nitrate (Ibirité reservoir,
Minas Gerais-SE Brazil): initial laboratory experiments. Braz J Biol 71:903-914

Jeppe KJ, Carew ME, Long SM, Lee SF, Pettigrove V, Hoffman AA (2014) Genes involved in cysteine metabolism of Chironomus tepperi are regulated differently by copper and by cadmium. Comp Biochem Physiol 162:1-6

Kellar CR, Hassell KL, Long SM, Myers JH, Golding L, Rose G, Kumar A, Hoffmann AA, Pettigrove V (2014) Ecological evidence links adverse biological effects to pesticide and metal contamination in an urban Australian watershed. J Appl Ecol $51: 426-439$

Lacey R, Watzin MC, Mcintosh AW (1999) Sediment organic matter content as a confounding factor in toxicity tests with Chironomus tentans. Environ Toxicol Chem 18:231-236

Leite I (2014) Água do volume morto de $2^{\mathrm{a}}$ represa do Cantareira começa a ser retirada: Captação de reserva técnica na Atibainha já era planejada, afirma Sabesp. Sistema acumula 100 dias consecutivos de queda no nível dos reservatórios. Veja. Accessed 1 Sept 2014

Li J, Zhou Q, Yuan G, He X, Xie P (2015) Mercury bioaccumulation in the food web of Three Gorges Reservoir (China): Tempospatial patterns and effect of reservoir management. Sci Total Environ 527-528:203-210

Logan M (2010) Biostatistical design and analysis using R: a practical guide. Wiley Blackwell, Oxford

Lotfi MN, Ahmed RS, El-Shatoury SA, Hanora A (2016) In situ morphological abnormalities in the mouthparts of Chironomus transvaalensis (nonbiting midges) stressing their role as bioindicators. J Entomol Zool Stud 4:1299-1305

Machado NG, Nassarden DCS, Santos F, Boaventura ICG, Perrier G, Souza FSC, Martins EL, Biudes MS (2015) Chironomus larvae (Chironomidae: Diptera) as water quality indicators along an environmental gradient in a neotropical urban stream. Rev Ambient e Água 10:298-309

Macomber L, Imlay JA (2009) The iron-sulfur clusters of dehydratases are primary intracellular targets of copper toxicity. Proc Natl Acad Sci 106:8344-8349

Madden CP, Suter PJ, Nicholson BC, Austin AD (1992) Deformities in chironomid larvae as indicators of pollution (pesticide) stress. Aquat Ecol 26:551-557

Martinez EA, Moore BC, Schaumloffel J, Dasgupta N (2002) The potential association between menta deformities and trace elements in Chironomidae (Diptera) taken from a heavy metal contaminated river. Arch Environ Contam Toxicol 42:286-291

Martins MVA, Mane MA, Frontalini F, Santos JF, da Silva FS, Terroso D, Miranda P, Figueira R, Laut LL, Bernardes C, Filho JG, Coccioni R, Dias JM, Rocha F (2015) Early diagenesis and clay mineral adsorption as driving factors of metal pollution in sediments: the case of Aveiro Lagoon (Portugal). Environ Sci Pollut Reserv Intern 22:19-33

Moreira-Santos M, Fonseca AL, Moreira SM, Osten JR, Silva EM, Soares AMV, Guilhermino L, Ribeiro R (2005) Short-term sublethal (sediment and aquatic roots of floating macrophytes) assays with a tropical chironomid based on postexposure feeding and biomarkers. Environ Toxicol Chem 24:2234-2242

Mozeto AA, Umbuzeiro GA, Jardim WF (2006) Métodos de coleta, análises físico-químicas e ensaios biológicos e ecotoxicológicos de sedimentos de água doce. Cubo Multimídia, São Carlos

Nikinmaa M (2014) An introduction to aquatic toxicology. Elsevier Inc, Oxford

Odume ON, Muller WJ, Palmer CG, Arimoro FO (2012) Mentum deformities in Chironomidae communities as indicators of anthropogenic impacts in Swartkops River. Phys Chem Earth 50$52: 140-148$ 
Oliveira V, Martins R, Alves R (2010) Evaluation of water quality of an urban stream in southeastern Brazil using Chironomidae larvae (Insecta: Diptera). Neotrop Entomol 39:873-878

Park K, Park J, Kim J, Kwak I-S (2010) Biological and molecular responses of Chironomus riparius (Diptera, Chironomidae) to herbicide 2,4-D (2,4-dichlorophenoxyacetic acid). Comp Biochem Physiol Part C 151:439-446

Pereira AMPT, Silva LJG, Meisel LM, Lino CM, Pena A (2015) Environmental impact of pharmaceuticals from Portuguese wastewaters: Geographical and seasonal occurrence, removal and risk assessment. Environ Res 136:108-119

Péry ARR, Ducrot V, Mons R, Garric J (2003) Modelling toxicity and mode of action of chemicals to analyse growth and emergence tests with the midge Chironomus riparius. Aquat Toxicol 65:281-292

Planelló R, Servia MJ, Gómez-Sande P, Herrero Ó, Cobo F, Morcillo G (2015) Transcriptional responses, metabolic activity and mouthpart deformities in natural populations of Chironomus riparius larvae exposed to environmental pollutants Environ Toxicol 30:383-395

Printes LB, Fernandes MN, Espíndola ELG (2011) Laboratory measurements of biomarkers and individual performances in Chironomus xanthus to evaluate pesticide contamination of sediments in a river of southeastern Brazil. Ecotoxicol Environ Saf 74:424-430. https://doi.org/10.1016/j.ecoenv.2010.10.033

Richardi VS, Vicentini M, Rebechi D, Fávaro F, Navarro-Silva MA (2015) Morpho-histological characterization of immature of the bioindicator midge Chironomus sancticaroli Strixino and Strixino (Diptera, Chironomidae). Revista Brasileira de. Entomologia 59:240-250. https://doi.org/10.1016/j.rbe.2015.07.00

Roman YE, Schamphelaere AC, Nguyen LTH, Janssen LT (2007) Chronic toxicity of copper to five benthic invertebrates in laboratory-formulated sediment: Sensitivity comparison and preliminary risk assessment. Sci Total Environ 387:128-140

Rousch JM, Simmons TW, Kerans BL, Smith BP (1997) Relative acute effects of low $\mathrm{pH}$ and high iron on the hatching and survival of the water mite (Arrenurus manubriator) and the aquatic insect (Chironomus riparius). Environ Toxicol Chem 16:2144-2150

Salmelin J, Vuori K-M, Hämäläinen H (2015) Inconsistency in the analysis of morphological deformities in chironomidae (insecta: diptera) larvae. Environ Toxicol Chem 34:1891-1898

Santos MAPF, Vicensotti J, Monteiro RTR (2007) Sensitivity of four test organisms Chironomus xanthus, Daphnia magna, Hydra attenuata and Pseudokirchneriella subcapitata) to $\mathrm{NaCl}$ : an alternative reference toxicant. J Braz Soc Ecotoxicol 2 (3):229-236

Sérvia MJ, Péry ARR, Heydorff M, Garric J, Lagadic L (2006) Effects of copper on energy metabolism and larval development in the midge Chironomus riparius. Ecotoxicology 15:229-240

Shanker AK, Cervantes C, Loza-Tavera H, Avudainayagam S (2005) Chromium toxicity in plants. Environ Int 31:739-753

Shrivastava A, Gupta VB (2011) Methods for the determination of limit of detection and limit of quantitation of the analytical methods. Chron Young-- Sci 2:21-25

Singh AK, Srivastava SC, Verma P, Ansari A, Verma A (2014) Hazard assessment of metals in invasive fish species of the Yamuna River, India in relation to bioaccumulation factor and exposure concentration for human health implications. Environ Monit Assess 186:3823-3836

Soares S, Cativa I, Moreira-Santos M, Soares AMV, Ribeiro R (2005) A short-term sublethal in situ sediment assay with Chironomus riparius based on postexposure feeding. Arch Environ Contam Toxicol 49:163-172

Sprague JB (1970) Measurement of pollutant toxicity to fish. II. Util Appl bioassay Results Water Res 4:3-32

Stanaway D, Haggerty R, Benner S, Flores A, Feris K (2012) Persistent metal contamination limits lotic ecosystem heterotrophic metabolism after more than 100 years of exposure: a novel application of the Resazurin Resorufin smart tracer. Environ Sci Technol 46:9862-9871

Strixino G, Trivinho-Strixino S (1985) A temperatura e o desenvolvimento larval de Chironomus sancticaroli (Diptera: Chironomidae). Rev Bras De Zool 3:177-180

Trivinho-Strixino S, Strixino G (1982) Ciclo de vida de Chironomus sancticaroli Strixino \& Strixino (Diptera: Chironomidae). Rev Bras De Èntomol 26:183-189

Trivinho-Strixino S, Strixino G (1989) Observações sobre a biologia da reprodução de um quironomídeo da região Neotropical (Diptera, Chironomidae). Revista Brasileira de. Entomologia 33:207-216

Trivinho-Strixino S (2011a) Chironomidae (Insecta, Diptera, Nematocera) do Estado de São Paulo, Sudeste do Brasil. Biota Neotrop 11:675-684

Trivinho -Strixino S (2011b) Larvas de Chironomidae: guia de identificação. UFSCar, São Carlos

Tundisi JG, Matsumura T (2008) Limnologia. Oficina de textos, São Paulo

United States Environmental Protection Agency - US - EPA (1996) Method 3050B: Acid digestion of sediments, sludges, and soils. https://www.epa.gov/sites/production/files/2015-06/documents/ epa-3050b.pdf. Accessed 27 July 2017

United States Environmental Protection Agency - US - EPA (1999), USA. Appendix E: Toxicity reference values: Screening level risk assessment protocol. In: Screening Level Ecological Risk Assessment Protocol for Hazardous Waste Combustion Facilities. US - EPA, Office of Solid Waste

Vogt C, Langer-Jaesrich M, Elasser O, Schmitt C, Van Dongen S, Köhler H-R, Oehlmann J, Nowak C (2012) Effects of inbreeding on mouthpart deformities of Chironomus riparius under sublethal pesticide exposure. Environ Toxicol Chem 32:423-425

Warwick WF, Tisdale NA (1988) Morphological deformities in Chironomus, Cryptochironomus, and Procladius larvae (Diptera: Chironomidae) from two differentially stressed sites in Tobi Lake, Saskatchewan. Can J Fish Aquat Sci 45:1123-1144

Wetzel RG, Likens GE (2000) Limnological analyses. Springer, New York, NY

Whately M, Cunha P (2007) Cantareira 2006: um olhar sobre o maior manancial de água da Região Metropolitana de São Paulo. Instituto Socioambiental, São Paulo

Xiao R, Bai J, Huang L, Zhang H, Cui B, Liu X (2013) Distribution and pollution, toxicity and risk assessment of heavy metals in sediments from urban and rural rivers of the Pearl River delta in southern China. Ecotoxicology 22:1564-1575 